\title{
Mobile Learning in Portuguese Universities: Are Professors Ready?
}

\author{
Fernando Moreira ${ }^{1,2,3}$, Carla Santos Pereira ${ }^{1,2}$, Natércia Durão ${ }^{1,2}$, Maria João \\ Ferreira $^{1,4}$, \\ ${ }^{1}$ Universidade Portucalense, DEGI, Rua Dr. António Bernardino de Almeida, 541, \\ 4200-070 Porto, Portugal \\ ${ }^{2}$ IJP, Universidade Portucalense, Portugal \\ ${ }^{3}$ IEETA, Universidade de Aveiro, Portugal \\ ${ }^{4}$ Centro Algoritmi, Universidade do Minho, Portugal \\ \{fmoreira, carlasantos, natercia, mjoao\}@upt.pt
}

\begin{abstract}
Mobile technology is increasingly an element to be considered in the new paradigm in education in general, and in higher education in particular. In addition, computers and information technology have increased educational opportunities and have opened the way to new teaching methods. Due to this, several concepts from the e-learning, m-learning and u-learning appeared. Therefore, it is critical to understand whether users (students and professors) are receptive and aware to adapt to this new paradigm before deciding to implement teaching-learning methods based on mobile technology. In this context, the aim of this paper is to investigate the perception of professors in higher education, the area of technology in Portugal in relation to m-learning, and to identify the needs of professors as they relate to mobile technologies and how they can be used to promote student's engagement inside and outside of the classroom.
\end{abstract}

Keywords: Mobile learning, Professors, mobile devices, Higher Education Institutions.

\section{Introduction}

The world is taking a bigger step when compared with changes found in the education sector. Peter Diamandis predicts that. [1] "in 2025, we'll see an acceleration in the rate of change as we move closer to a world of true abundance". Moreover, he presented some numbers that illustrate very well what we can expect for the near future. For instance, with a trillion sensors gathering data everywhere (autonomous cars, satellite systems, wearables...), we will be able to know anything what we want, anytime, anywhere, and query that data for answers. This rapid evolution complemented by generations of students born with digital technology, leads to having a significantly different approach to learning. In this context, students are used to have access to multiple sources of information in real time, running multitasking, 
socially connected with their peers via mobile devices (MD), leading to necessary new solutions compared to current teaching-learning processes (TLP).

The rapid spread of MD by the world's population is shown by the World Bank Institute [2], where the number of people using smartphones increased from less than 700 million in early 2000 to more than 5 billion or $70 \%$ of the world population, in 2010.

With this growth, we would expect further evolution of the concepts of learning, particularly in higher education institutions (HEI), once these institutions have gone through rapid changes, especially during the last 10 years [3]. In addition, computers and information technology have increased educational opportunities and have opened the way to new teaching methods. Due to this, several concepts from the elearning, m-learning and u-learning [4] appeared. However, it was expected that the concept of mobile learning (m-learning) had a greater evolution, because both students and professors are more enlightened technology [5].

The students of HEIs have mobile technologies and Internet access in and out of institutions. These technologies have enabled access to resources related to their studies allowing them the framework for m-learning scenarios [5]. However, these two factors are some of the factors that allow mobile learning to develop. As learning is a subjective construction in which students must be fully involved, Spiegel and Rodríguez [6] raises the question "Which are the necessary requirements to let mobile technologies for tools become their task of studying and building knowledge?". According to [6] and [7] for the learning potential it is required the occurrence a set of factors that have to be articulated, including the professor's role [8].

Before thinking of designing and implementing an m-learning system, it is important to check the perception of future users regarding mobile learning since its perception, which will influence their willingness and readiness to use the system [9]. In [10] it is shown that today's professors have difficulties in being familiarized with the digital language of their students, making it difficult to maximize their learning through models implemented through m-learning. Thus, there is a need for qualified professors in m-learning models. As a result, the successful integration of m-learning technologies in education require the perception of these technologies by professors, so it is possible to ask the question "How do professors percept m-learning?" In this context, the aim of this paper is to investigate the perception of professors in higher education, the area of technology in Portugal in relation to m-learning, and to identify the needs of professors as they relate to mobile technologies and how they can be used to promote student's engagement inside and outside of the classroom.

\section{State of the art}

As previously discussed, the m-learning offers students and professors unique features that did not exist in traditional learning platforms, for example, in e-learning. One of the most interesting features is that the mobility refers to the perspective to have flexibility in terms of time, location, time and space that cannot be taken when training is from another type [11]. The second important feature, and possible with $\mathrm{m}$ learning, is collaborative learning, because the use of MD with Internet access inside 
and outside the classroom, will enable students to interact in a more easily, with other students and professors in different physical locations.

The features discussed above in relation to the participation of professors in this process are already the subject of several researches [12]. The author presents a study with a review of research on mobile learning in teacher education where 37 papers were analysed. In addition to works found in [12], other studies show some results concerning this subject.

In [13] a research work on the perception of professors in Indonesia in relation to $\mathrm{m}$-learning is presented to determine their willingness to participate in the use of $\mathrm{m}$ learning in teaching. The obtained results show that Indonesian professors have a positive perception regarding the use of m-learning.

The study presented in [14] can be interpreted by the m-learning, from the perspective of professors, has a positive effect on student motivation for learning mathematics and the relationship between m-learning and a variety of teaching methods is positive and significant.

In [15] the authors have presented the results of a detailed and systematic investigation into the critical success factors affecting user perception of m-learning from the perspective of professors. As a result, the professors are one of the crucial user groups, so it is important to understand the factors they consider crucial for the success of mobile learning. The results showed that none of the factors analysed were statistically significant.

US-based study presented in [16] realized that another reason why the HEIs are not receptive to the adoption of m-learning is because students would use the devices to socialize and not to perform tasks related to the TLP and, so most professors prohibited the devices in the classroom.

Uzunboylu and Ozdamli [17] presented a study which shows that the success of mlearning integration in education requires first, to be determined the perception of professors regarding the technology to be used. The problems that the authors found were the lack of an instrument to do the evaluation of the teacher's perception. The result of the study showed that professors in Cyprus have average levels of perception regarding adoption of m-learning.

The number of papers on the applicability of m-learning from the professors' point of view is reduced globally, and it was verified that does not exist papers relating to HEIs in Portugal. After the survey conducted during the period of 2009-2016 and using the following query search: "(professors OR professors) AND (mobile learning OR m-learning) AND Portugal", it was the inexistence of any paper. In this context, from this study it was possible to conclude that there is no study on mobile technologies in education, particularly in HEIs in Portugal, thus making it relevant and justified.

\section{Research methodology}

The purpose of this section is to describe the procedures used to collect data that are the basis for this research. The main feature of the scientific method is an organized research, strict control of the use of observations and theoretical knowledge. 
For the present study, we used the methodology of quantitative research, since it is more appropriate to determine the opinions and attitudes of the respondent based on structured questionnaires. In this approach, data is collected through structured questionnaires, and clear goals in order to ensure uniform compression of the respondents and a consequent standardization of results.

The undertaken study was descriptive in nature. Data collected for quantitative research through the use of questionnaires requires special care because it is not enough to collect responses about the issues of interest, it is also important to know how to do statistical analysis for proper results validation. Aspects such as the sample size, the way the questionnaire is prepared, the questions formulation, data analysis, error margins, the selection of individual process of who should compose the sample, among other things, are important and they should be taken into account for any investigation [18]. This method is recommended when you want to know a population, to analyse social phenomena and, in cases where it is necessary to inquire a big number of people about a certain subject. The questionnaire before being delivered was subjected to the evaluation of four experts in the field.

The aim of this study is to investigate the perception of professors in higher education, the area of technology in HEIs in Portugal in relation to m-learning, and to identify the needs of professors as they relate to mobile technologies and how they can be used to promote student's engagement inside and outside of the classroom. The quantitative study was based on an online questionnaire with 6 sections (Demographic information, Prior knowledge, Participation/Engagement, Use of Mobile Devices, Mobile use in the classroom and Self-efficacy) and 41 questions (Q1-Q41). The first section consists of 6 questions, which include, for example, the age and gender. Second section contains a question (Q7) with 11 items about the information that the professors know about MD. The third section contains 18 questions about their opinion of Participation/Engagement of the students in the use of MD in activities inside and outside of the classroom. As for the fourth section, it contained a question with 18 items about how to use MD in the classroom. In section five we ask 12 questions about using MD in the classroom. Finally, in the last section we have 3 questions about self-efficacy. Almost all questions were close-ended type. Sections 3 and 5 use five-point Likert scale ranging from "Strongly Disagree" (1) to "Strongly Agree" (5).

The questionnaire has been online for 60 days and 37 valid responses were received. Data collected were pooled and treated by using the IBM SPSS Statistics 24.0 software. Statistical analyses used for the data analysis were descriptive analysis, reliability analysis and correlation analysis (Spearman's rho and Pearson correlation).

\section{Analysis and discussion of results}

The study sample consists of 37 professors from higher education in the area of technology in HEIs in Portugal. Most respondent's gender were male $(64,9 \%)$ whereby, the majority of professors were aged between 41 to 50 years old $(59,5 \%)$. As for teach program, $73 \%$ of them teach in $\mathrm{PhD}, 78,4 \%$ in Master and $51,4 \%$ in Degree. Since professors can simultaneously teach various levels of education, we 
find interesting to cross these data with the ages. It was concluded that, the youngest only teach in the under degree, and the higher the age group, the more levels of education they teach.

When it comes to the matter of "Prior Knowledge", Table 1 shows the results of percentages of Yes and No responses of the 11 items of question Q7.

Table 1. Percentages of Yes and No responses of the 11 items of question Q7.

\begin{tabular}{|c|c|c|c|}
\hline Item & & Yes/No & $(\%)$ \\
\hline \multirow{2}{*}{1} & \multirow{2}{*}{ Connect to and access the internet from a MD } & No & 0,0 \\
\hline & & Yes & 100,0 \\
\hline \multirow{2}{*}{2} & \multirow{2}{*}{ Download music and video files on a MD } & No & 10,8 \\
\hline & & Yes & 89,2 \\
\hline \multirow{2}{*}{3} & \multirow{2}{*}{ Find the definition of a word or concept on a MD } & No & 8,1 \\
\hline & & Yes & 91,9 \\
\hline \multirow{2}{*}{4} & \multirow{2}{*}{ Download a mobile application on a MD } & No & 2,7 \\
\hline & & Yes & 97,3 \\
\hline \multirow{2}{*}{5} & \multirow{2}{*}{ Interface or connect my calendar/alarm on a MD } & No & 18,9 \\
\hline & & Yes & 81,1 \\
\hline \multirow{2}{*}{6} & \multirow{2}{*}{ Translate a sentence into another language on a MD } & No & 13,5 \\
\hline & & Yes & 86,5 \\
\hline \multirow{2}{*}{7} & \multirow{2}{*}{ Access and participate in a social network site on a MD } & No & 10,8 \\
\hline & & Yes & 89,2 \\
\hline \multirow{2}{*}{8} & \multirow{2}{*}{ Send and receive emails/text messages on a MD } & No & 5,4 \\
\hline & & Yes & 94,6 \\
\hline \multirow{2}{*}{9} & \multirow{2}{*}{ Access college resources such as LMS, payroll, etc., on a MD } & No & 18,9 \\
\hline & & Yes & 81,1 \\
\hline \multirow{2}{*}{10} & \multirow{2}{*}{ Download augmented reality applications on a MD } & No & 29,7 \\
\hline & & Yes & 70,3 \\
\hline \multirow{2}{*}{11} & \multirow{2}{*}{ Download Mobile App Gamification on a MD } & No & 29,7 \\
\hline & & Yes & 70,3 \\
\hline
\end{tabular}

We note that the majority of Portuguese professors (even regardless of age) have knowledge on how to perform the most trivial tasks (such as connect and access internet, access college resources such as LMS and payroll) with percentages above $80 \%$. Although still very high $(70,3 \%)$, we found a decrease when the prior knowledge is related to download augmented reality applications and download Mobile App Gamification on a MD (items 10 and 11).

In order to verify if the variability of the answers resulted from the differences between the opinions of each professor, we performed a reliability analysis to verify the existence of internal consistence measured by Cronbach's Alpha. The value of alpha varies from 0 to 1 and higher values of alpha are more desirable.

Table 2 shows the results of Cronbach's Alpha for evaluate two dimensions (sections), which are "Participation/Engagement" (Dimension 1) and "Mobile use in the classroom" (Dimension 2). 
Table 2. Cronbach's Alpha coefficients.

\begin{tabular}{lcc}
\hline Dimension & Cronbach's Alpha & N of Items \\
\hline 1. Participation/Engagement & 0,928 & 18 \\
2. Mobile use in the classroom & 0,909 & 10 \\
\hline
\end{tabular}

As can be observed, the Cronbach's Alpha coefficients for both dimensions exceed 0,9 which is considered excellent [19]. Therefore, both dimensions in this study were deemed to be reliable. Thus, it makes sense to present the descriptive results (mean-m and standard deviation-sd) for each question (variable). The results of the analysis can be found, resumed, in Table 3 and 4 (Dimension 1 and Dimension 2, respectively).

Table 3. Descriptive Statistics for each question of Dimension 1.

\begin{tabular}{|c|c|c|}
\hline Question & Mean & SD \\
\hline $\begin{array}{l}\text { Q8 - My students would be more likely to participate in classes if they could use } \\
\text { their MD }\end{array}$ & 3,54 & 1,04 \\
\hline $\begin{array}{l}\text { Q9 - Mobile learning opportunities would allow students to learn and study in } \\
\text { places they normally couldn't }\end{array}$ & 4,35 & 0,72 \\
\hline $\begin{array}{l}\text { Q10 - It would be easier for students to complete classwork and assignments if } \\
\text { they could use MD }\end{array}$ & 3,57 & 1,28 \\
\hline $\begin{array}{l}\text { Q11 - My students would spend more time on classwork if they could access } \\
\text { materials anytime, anywhere on their MD }\end{array}$ & 3,32 & 1,16 \\
\hline $\begin{array}{l}\text { Q12 - My students would be more likely to participate in class activities outside } \\
\text { of the class time if they could do that through their MD }\end{array}$ & 3,62 & 1,09 \\
\hline $\begin{array}{l}\text { Q13 - My students would be more likely to engage in class discussions inside of } \\
\text { class they could post their thoughts from their MD }\end{array}$ & 3,65 & 1,11 \\
\hline $\begin{array}{l}\text { Q14 - My students would be more likely to engage in class discussions outside of } \\
\text { class they could post their thoughts from their MD }\end{array}$ & 3,95 & 0,91 \\
\hline $\begin{array}{l}\text { Q15 - My students would be more likely to ask for help if they could } \\
\text { communicate through their MD }\end{array}$ & 3,65 & 1,11 \\
\hline be incorporated into classes & 3,97 & 0,83 \\
\hline be incorporated into ML classes & 4,00 & 1,08 \\
\hline Q18 - Gamification could be incorporated into ML classes & 4,08 & 1,01 \\
\hline Q19 - Students should be able to easily view course materials on their MD & 4,38 & 0,79 \\
\hline $\begin{array}{l}\text { Q20 - Students should be able to download mobile applications that could help } \\
\text { them study }\end{array}$ & 4,59 & 0,55 \\
\hline $\begin{array}{l}\text { Q21 - Students should be able to access LMS (e.g. Moodle..) in a mobile format } \\
\text { on their MD }\end{array}$ & 4,59 & 0,64 \\
\hline Q22 - Students should be able to take quizzes on their MD & 4,30 & 1,05 \\
\hline Q23 - Students should be able to participate in discussion forums from their MD & 4,54 & 0,65 \\
\hline $\begin{array}{l}\text { Q24 - It would not require a lot of effort for students to learn how to use a mobile } \\
\text { application designed for my class }\end{array}$ & 4,08 & 1,01 \\
\hline Q25 - It would be easy for students to engage in discussions using mobile & & 0,8 \\
\hline
\end{tabular}

As can be seen in Table 3, in terms of Participation/Engagement, the overall mean value of 4,015 which is above the neutral position of 3 suggested that professors think that the students will have greater involvement and participation in activities (inside and outside the classroom) if they use their MD. 
As an example, professors strongly agree $(\mathrm{m}=4,59)$ that students should be able to download mobile applications that could help them study (Q20) and should be able to access LMS (Q21). It should be noted that in both variables the opinions are consistent since standard deviations are reduced $(\mathrm{sd}=0,551$ and $\mathrm{sd}=0,644$, respectively). In this dimension the lowest value $(\mathrm{m}=3,32, \mathrm{sd}=1,156)$ for $\mathrm{Q} 11$ ("My students would spend more time on classwork if they could access materials anytime, anywhere on their MD") shows a positive opinion of professors regarding the use of MD and since the variability is high, the answer to this question is not as homogeneous as the previous ones (Q20 and Q21).

Table 4. Descriptive Statistics for each question of Dimension 2.

\begin{tabular}{lrr}
\hline Question & Mean & SD \\
\hline $\begin{array}{l}\text { Q27 - I believe students can be taught how to appropriately use MD for } \\
\text { learning }\end{array}$ & 4,19 & 0,81 \\
\hline $\begin{array}{l}\text { Q28 - I believe students can be taught how to appropriately use MD for } \\
\text { collaborative learning }\end{array}$ & 4,30 & 0,70 \\
\hline $\begin{array}{l}\text { Q29 - I believe students can be taught how to appropriately use MD with } \\
\text { augmented reality apps for learning }\end{array}$ & 4,05 & 0,94 \\
\hline $\begin{array}{l}\text { Q30 - I believe students can be taught how to appropriately use MD with } \\
\text { gamification apps for learning }\end{array}$ & 4,05 & 0,94 \\
\hline $\begin{array}{l}\text { Q31 - I believe using mobile applications for learning in my classroom would } \\
\text { benefit students }\end{array}$ & 3,57 & 1,14 \\
\hline $\begin{array}{l}\text { Q32 - I think students would be more motivated to learn if they could use } \\
\text { MD }\end{array}$ & 3,76 & 1,09 \\
\hline Q33 - Students would think is fun to use an interactive MD in my classroom & 4,03 & 0,96 \\
\hline $\begin{array}{l}\text { Q34 - I would like my students to be able to use MD to access course } \\
\text { contents and practical skills }\end{array}$ & 3,97 & 0,93 \\
\hline $\begin{array}{l}\text { Q35 - I would like to learn more about m-learning, so that I can incorporate } \\
\text { it in my classroom }\end{array}$ & 3,81 & 1,15 \\
\hline $\begin{array}{l}\text { Q36 - I would like to learn more about m-learning, so that I can incorporate } \\
\text { them into my lessons }\end{array}$ & 3,89 & 1,15 \\
\hline
\end{tabular}

Table 4 shows the results of Dimension 2, "Mobile use in the classroom", analysis. The overall mean value of 3,957 which is above the neutral position of 3 suggested that professors are in agreement about students using MD in the classroom. As can be observed, most professors strongly agree $(\mathrm{m}=4,30)$ that students can be taught how to appropriately use MD for collaborative learning (Q28). Professors also somehow agree $(\mathrm{m}=3,57)$ that using mobile applications for learning in their classroom would benefit students (Q31).

In order to evaluate if, eventually, older professors would have a more conservative opinion relatively to the Participation/Engagement in the use of MD in education (variables from Dimension 1), we calculated, bearing in mind their measurement scale (ordinal scale), Spearman's rho coefficient. Even though not very significant, we found a tendency for older professors to be less involved, since there was a predominance of negative relationship. Moreover, the only variable which had a significant correlation at the 0,01 level (2-tailed) is Q23 ("Students should be able to participate in discussion forums from their MD") in which $r_{s}=-0,46$. 
When it comes to the matter of "Use of MD" (Q26), in the sense, of what educational tasks professors ask students to do inside or outside the classroom, we calculated the percentages of Yes and No responses of the 18 items of question. It is important to highlight the high percentages of Yes (between $70 \%$ and $78 \%$ ) for the items "Download applications, write notes, take a picture or video, read a paper use MD as study tool, etc. Relatively to No responses, it is important to mention the high percentages (between $73 \%$ and $81 \%$ ), for the items referring to "Text a classmate" during the class, about the professor's ability and the level of engagement in the class.

In order to incorporate m-learning in future classroom, $45,9 \%$ and $40,5 \%$ of the professors said that will be able to effectively incorporate m-learning into their classroom without and with training, respectively. Only 13,5\% do not think will be able to effectively incorporate m-learning into their classroom.

Professors are very confident (percentage above $89 \%$ ) that can use Internet, take photos or videos, read and understand contents, navigate and participate in discussions, using MD.

On the other hand, most of the professors (between $76 \%$ and 95\%) think that will need to be able to have access to the Internet inside or outside the class, securely authenticate to the online instructional resources, easy and affordable access to acquiring $\mathrm{MD}$, navigate a mobile application on a MD and have professional development opportunities on how to use mobile applications.

Finally, as Cronbach's Alpha coefficients for both dimensions shown an excellent intern consistency, we can continue the analysis by building two indices constituted by the arithmetic average of the variables which constitute each dimension. So, we created the indices, "mean_D1" e "mean_D2" which summarize the information given by the variables which integrate them and represent the respective average score. In order to identify if there was a relationship between the indices "mean_D1" and "mean_D2" we calculate Pearson correlation coefficient. Correlation analysis confirms the significant positive relationship $(\mathrm{r}=0,849)$ at the 0,01 level (2-tailed), that is, the professors that most agree in Dimension 1 (Participation/Engagement) are those who agree the most in Dimension 2 (Mobile use in the classroom).

Curiously, we concluded that there are more female professors who think that students will have a higher involvement and participation in the activities (inside and outside the classroom) if they use their MD, compared to the number of male professors and relatively to Dimension 2 (Mobile use in the classroom) this opinion is even more evident (see Figure 1). Furthermore, male professors have more consistent opinions that female professors. 

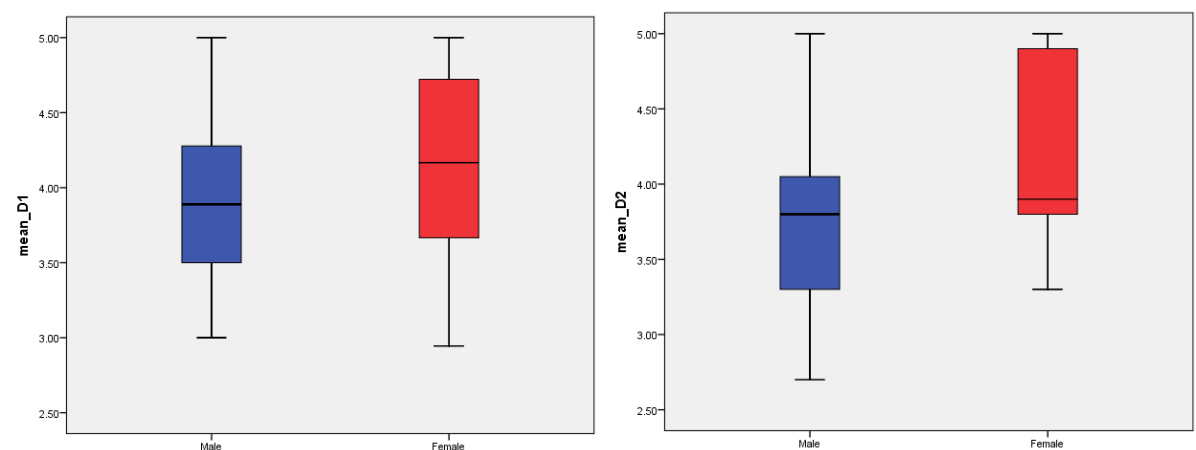

Fig. 1. Boxplot for indices "mean_D1" e "mean_D2" by sex

\section{Conclusions and future work}

With the purpose of meeting the generations of students born with digital technology, it is necessary to make an adaptation of the TLP, in order accommodate new technologies. Therefore, it is critical to understand whether users (students and professors) are receptive and aware to adapt to this new paradigm before deciding to implement teaching-learning methods based on mobile technology.

As a result, the successful integration of m-learning technologies in education require the perception of these technologies by professors, so it is possible to ask the question "How do professors percept m-learning?". In this context, the aim of this paper is to investigate the perception of professors in higher education, in the area of technology in Portugal in relation to m-learning, and to identify the needs of professors as they relate to mobile technologies and how they can be used to promote student's engagement inside and outside of the classroom.

As can be seen by the statistical analysis and discussed in the previous section, for both dimensions, all professors, regardless of age, they are receptive and believe in capital gains from the introduction of MD in the TLP. It is interesting to note that the answers to the question 7 , when questioned on the use of augmented reality applications and gamification results show a smaller difference between the Yes $(70.3 \%)$ and No $(29.7 \%)$, unlike of the trend of responses to other items, with Yes (> $81.0 \%$ ) and No (14.0\%). However, professors identify, in Dimension 2, questions Q28, Q29 and Q30, the added value of the introduction together with the MDs in collaborative learning, augmented reality and gamification. It is further noted that there is greater agreement on the Participation/Engagement, than the effective use of MDs in and out of the classroom for the students, from the perspective of professors.

As future work, the study will be extended to the Iberian Peninsula, initially using the same survey in order to understand the difference in perception by professors on the introduction of m-learning in the TLP. Additionally, we will study how HEIs are promoting courses or course contents specifics for mobile learning. 


\section{References}

1. Diamandis, P.: The World in 2025. http://78.46.45.106/ eira/index.php/talk-thetrends/item/2045-the-world-in-2025-by-peter-diamandis

2. The World Bank Institute: Behavioral change using technology. Retrieved March 1, 2014, from http://wbi.worldbank.org/wbi/content/behavioral-change-using-technology (2012).

3. Hursen Ç., Ozcinar Z., Ozdamli F., Uzunboylu H.: The communicative competences of students and professors in different levels of education in North Cyprus. Asia Pacific Education Review 12, pp. 59-66 (2010)

4. Park, Y.: A Pedagogical Framework for Mobile Learning: Categorizing Educational Applications of Mobile Technologies into Four Types, The International Review of Research in Open and Distance Learning, Vol.12, No.2, February. http://www.irrodl.org/index.php/irrodl/article/view/791/1699 (2011)

5. Moreira, F., Ferreira, M.J., Santos Pereira, C., Durão, N.: Evolution and use of mobile devices in higher education: A case study in Portuguese Higher Education Institutions between 2009/10 and 2014/15. Telematics and Informatics Journal. (2016). http://dx.doi.org/10.1016/j.tele.2016.08.010

6. Spiegel, A., Rodríguez, G.: Students at university have mobile technologies. Do they do mlearning? Procedia - Social and Behavioral Sciences, 217, pp. 846 - 850 (2016).

7. Levy, P.: O que é o virtual. São Paulo: Ed. 34, (1996)

8. Morris D.: E-confidence or incompetence: are professors ready to teach in the 21 st century? World Journal on Educational Technology 2, pp. 141-154 (2010).

9. Yusri, I. K., Goodwin, R., Mooney, C.: Professors and mobile learning perception: towards a conceptual model of mobile learning for training. Procedia - Social and Behavioral Sciences 176, pp. 425 - 430. (2015).

10. Corbeil R.J., Corbeil V.E.M.: Are you ready for mobile learning? Educase Quarterly Magazine 30, pp. 51-58 (2007)

11. Andrews, T., Smyth, R., Tynan, B., Berriman, A., Vale, D., Cladine, R.: Mobile technologies and rich media: expanding tertiary education opportunities in developing countries. In A. G. Abdel-Wahab, \& A. A. El-Masry, Mobile Information Communication Technologies Adoption in Developing Countries: Effects and Implication. New York: Idea Group Inc. (2010).

12. Baran, E. A Review of Research on Mobile Learning in Teacher Education. Educational Technology \& Society, 17 (4), pp.17-32 (2014).

13. Yusri, I. K., Goodwin, R., Mooney, C.: Teachers and mobile learning perception: towards a conceptual model of mobile learning for training. Procedia - Social and Behavioral Sciences 176, pp. $425-430$ (2015)

14. Taleb, Z., Ahmadi, A., Musavi, M.: The effect of m-learning on mathematics learning Procedia - Social and Behavioral Sciences 171 pp. 83 - 89 (2015)

15. Alrasheedi, M., Capretz, L. F.: An empirical study of critical success factors of mobile learning platform from the perspective of instructors. Procedia - Social and Behavioral Sciences 176, pp. $211-219$ (2015).

16. Pollara, P.: Mobile learning in higher education: A glimpse and a comparison of student and faculty readiness, attitudes and perceptions. Baton Rouge: Louisiana State University (2011).

17. Uzunboylu, H., Ozdamli, F.: Teacher perception for m-learning: scale development and professors' perceptions. Journal of Computer Assisted Learning, 27, pp. 544 -556 (2011)

18.Campenhoudt, L-V., Quivy, R.: Manual de Investigação em Ciências Sociais, Gradiva Publicações, (2008).

19. Pestana, M.H., Gageiro, J.N. Análise de dados para Ciências Sociais. A complementaridade do SPSS. (6ª edição) Lisboa: Edições Sílabo (2014). 